\title{
ПАРТИСИПАЦІЯ ПАЦІЕНТІВ ЯК ЕЛЕМЕНТ ЗАБЕЗПЕЧЕННЯ БЕЗПЕКИ НАДАННЯ МЕДИЧНОЇ ДОПОМОГИ - ОСОБЛИВОСТІ ДИСТАНЦІЙНОГО ФОРМАТУ
}

\author{
О. П. Мінцер, Н. В. Мироненко, Н. О. Сінєнко, А. М. Новик \\ Національна медична академія післядипломної освіти імені П. Л. Шупика
}

\begin{abstract}
Представлено питання впровадження концепції «4Р» у практичну медицину. Проаналізовано проблеми комплексного лікування пацієнтів, партисипації та безпеки пацієнтів. Зроблено висновки, що серед складових ефективної медицини міждисциплінарні підходи видаються особливо актуальними та важливими в контексті цифрових медичних послуг. Вони впливають як на загальний процес прийняття рішень, так і на всі інші ключові елементи в послідовності процедур надання медичної допомоги - комунікаційні процеси, логіку партисипації і, навіть, на отримання інсрормованої згоди від пацієнта. Підкреслено, що необхідні нові нормативно-правові акти стосовно відповідальності окремих учасників надання медичної допомоги, особливо у випадках дистанційної (мобільної) медицини, стандарти щодо конфоденційності та якості даних обстеження, моніторингу стану здоров'я пацієнтів. Акцентовано також, що забезпечення безперервності надання медичної допомоги, в тому числі й у дистанційному фрорматі, в рамках комплексної (трансмуральної) моделі організації охорони здоров'я потребує єдиної шкали оцінювання надання медичної допомоги.
\end{abstract}

Ключові слова: комплексне (трансмуральне) лікування пацієнтів, партисипація пацієнтів, мобільна медицина, мультидисциплінарні підходи, безперервне надання медичної допомоги.

\section{PARTICIPATION OF PATIENTS AS AN ELEMENT OF SAFETY PROVISION - SPECIFIC FEATURES OF THE REMOTE FORMAT}

\author{
O. P. Mintser, N. V. Myronenko, N. O. Sinienko, A. M. Novyk \\ Shupyk National Medical Academy of Postgraduate Education
}

\begin{abstract}
Background. The questions of introduction of the concept «4P» in practical medicine are considered. The problems of complex treatment of patients, participation and safety of patients are analyzed.

Materials and methods. Results. The aim of the study is to substantiate the importance of the components of modern effective medicine: participation, communication, informatization, creation of multidisciplinary teams, as well as their changes in mobile medicine.

Among the components of effective medicine, multidisciplinary approaches appear to be particularly relevant and important in the context of digital health services. It is emphasized that new regulatory acts are needed regarding the responsibilities of individual participants in the provision of medical care, especially in the case of remote (mobile) medicine, standards regarding the confidentiality and quality of patient survey and monitoring data.

Conclusions. Multidisciplinary approaches affect both the overall decision-making process and all other key elements in the sequence of care delivery procedures - communication processes, the logic of participation, and, even, obtaining informed consent from the patient. It is also emphasized that ensuring continuity of care delivery, including the remote format, within a comprehensive (transmural) model of health care organization requires a unified scale of assessment of care delivery.
\end{abstract}

Key words: complex (transmural) treatment of patients, patient participation, mobile medicine, multidisciplinary approaches, continuous medical care. 


\title{
ПАРТИСИПАЦИЯ ПАЦИЕНТОВ КАК ЭЛЕМЕНТ ОБЕСПЕЧЕНИЯ БЕЗОПАСНОСТИ ПРЕДОСТАВЛЕНИЯ МЕДИЦИНСКОЙ ПОМОЩИ - ОСОБЕННОСТИ ДИСТАНЦИОННОГО ФОРМАТА
}

\author{
О. П. Минцер, Н. В. Мироненко, Н. А. Синенко, А. М. Новик
}

Национальная медицинская академия последипломного образования имени П. Л. Шупика

\begin{abstract}
Представлены вопросы внедрения концепции «4Р» в практическую медицину. Проанализированы проблемы комплексного лечения пациентов, партисипации и безопасности пациентов. Цель работы: обоснование значимости составляющих современной эффективной медицины - партисипации, коммуникации, информатизации, создания междисциплинарных команд, а также их изменения в мобильной медицине. Сделаны выводы, что среди составляющих эффективной медицины междисциплинарные подходы представляются особенно актуальными и важными в контексте цифровых медицинских услуг. Они влияют как на общий процесс принятия решений, так и на все другие ключевые элементы в последовательности процедур оказания медицинской помощи - коммуникационные процессы, логику партисипации и даже на получение инфрормированного согласия пациента. Подчеркнуто, что необходимы новые нормативно-правовые акты об ответственности отдельных участников оказания медицинской помощи, особенно в случаях дистанционной (мобильной) медицины, стандарты конфриденциальности и качества данных обследования и мониторинга состояния здоровья пациентов. Акцентировано также, что обеспечение непрерывности оказания медицинской помощи, в том числе и в дистанционном фрормате, в рамках комплексной (трансмуральной) модели организации здравоохранения, нуждается в единой шкале оценки оказания медицинской помощи.
\end{abstract}

Ключевые слова: комплексное (трансмуральное) лечение пациентов, партисипация пациентов, мобильная медицина, мультидисциплинарные подходы, непрерывное оказание медицинской помощи. 
Вступ. Останнім часом швидке розповсюдження отримало комплексне лікування пацієнтів. Воно також відоме як комплексна охорона здоров' я, скоординоване лікування, комплексне лікування, безперервне лікування або трансмуральне лікування та розглядається як відповідь на фрагментарне надання медичних і соціальних послуг, що є загальновизнаною проблемою в багатьох системах охорони здоров’я. ВООЗ дає таке визначення: «Комплексна медична допомога — це концепція, що об’єднує ресурси, надання, управління й організацію послуг, пов’ язаних із діагностикою, лікуванням, доглядом, реабілітацією та зміцненням здоров’я. Інтеграція $\epsilon$ засобом поліпшення послуг щодо доступу, якості, задоволеності користувачів і ефективності». Стратегія подібного лікування є загальносвітовою тенденцією в реформуванні охорони здоров’я та нових організаційних механізмах, орієнтованих на більш скоординовані та інтегровані форми надання медичної допомоги.

Другою тенденцією еволюції медицини є те, що все більша кількість пацієнтів, зокрема з хронічними захворюваннями, потребують міждисциплінарного підходу. Подібна тенденція підвищує потребу в обміні інформацією між фахівцями та лікарями для забезпечення безперервності надання медичної допомоги в рамках зазначеної комплексної (трансмуральної) моделі.

Мета роботи: обгрунтувати значимість складових сучасної ефективної медицини: партисипації, комунікації, інформатизації, створення міждисциплінарних команд, а також їх змінення в мобільній медицині.

Результати та ї обговорення. Можна стверджувати, що практика надання медичної допомоги критично залежить від ефективної і дієвої комунікації, а також обгрунтованої партисипації пацієнтів. Підкреслимо, що в сучасній реляційній персоналізованій етичній перспективі точка зору пацієнта та досвід співпраці між лікарем і фахівцями не менш важливі, ніж сприйняття ситуації з боку фахівців охорони здоров’я.

Безперервність догляду за пацієнтом, об’єднання окремих і дискретних елементів догляду в тривалий процес забезпечення безпеки пацієнтів страждають від неадекватної комунікації. Вочевидь, що інформація про попередні події може вплинути на поточні рішення стосовно догляду за пацієнтом і що відсутність або неповнота такої інформації може призвести до несприятливих подій і подальших ризиків для безпеки пацієнта. Як наслідок, коли правильна інформація недоступна певному лікарю в потрібний час, безпека пацієнта може бути поставлена під загрозу.

Мультидисциплінарні підходи сьогодні вважаються особливо актуальними в контексті цифрових медичних послуг. Хоча, юридичні питання, пов’язані з приватним життям, правами інтелектуальної власності, обміном інформацією, наданням транскордонної допомоги, можуть потребувати особливої уваги. Це може додавати складності й кількісним оцінкам ефективності надання медичної допомоги. Дві цифрові медичні послуги можуть бути однаково гарними, але якщо страждають питання сумісності, використання обох послуг все одно буде неоптимальним.

Оскільки цифрові медичні послуги є поєднанням «цифрових» і «медичних» компонентів, рамки оцінювання цифрових медичних послуг можуть підкреслювати саме цифрові аспекти медичних послуг, що підлягають оцінюванню. В цьому сенсі важливо також виділити деякі елементи, властиві здоров'ю. Це, наприклад, може стосуватися телемедицини, де можуть бути необхідні нові нормативно-правові акти стосовно відповідальності або стандартів щодо конфіденційності та якості даних для потоків інформації. Підкреслимо, що забезпечення безперервності надання медичної допомоги, в тому числі й у дистанційному форматі, в рамках комплексної (трансмуральної) моделі організації охорони здоров’ я потребує єдиної шкали оцінювання надання медичної допомоги.

Важливо зауважити на ще одному з важливих елементів партисипації - інформованому прийнятті рішень. Підкреслимо, що це двосторонній процес комунікації між пацієнтом та одним або декількома лікарями, що займає центральне значення в системі охорони здоров' я, яка орієнтована на пацієнта. Він відображає етичний принцип того, що пацієнт має право вирішити, що йому підходить, враховуючи свої особисті обставини, переконання та пріоритети. Для того, щоб пацієнти скористалися цим правом приймати рішення, їм потрібна інформація, яка стосується їх.

Висновки. 1. Серед складових ефективної медицини міждисциплінарні підходи видаються особливо актуальними та важливими в контексті цифрових медичних послуг. Вони впливають як на загальний процес прийняття рішень, так i на всі інші ключові елементи в послідовності процедур надання медичної допомоги 
— комунікаційні процеси, логіку партисипації i, навіть, на отримання інформованої згоди від пацієнта.

2. Необхідні нові нормативно-правові акти стосовно відповідальності окремих учасників надання медичної допомоги, особливо у випадках дистанційної (мобільної) медицини, стандартів щодо

\section{Література.}

1. Integrated Care: Meaning, Logic, Applications, and Implications - A discussion paper / Kodner D. L., Spreeuwenberg C. // International Journal of Integrated Health Care Archive. - T. 2. - C. 12.

2. Trends in Integrated Care - Reflections on Conceptual Issues / Gröne O., Garcia-Barbero M. - Copenhagen: World Health Organization, 2001. - 10 c.

3. Medicine as a community of practice: Implications for medical education / Cruess R. L., Cruess S. R., Steinert Y. // Acad Med. — 2018. — № 93. — C. 185-191.

4. Quantifying the economic impact of communication inefficiencies in U.S. hospitals / Agarwal R., Sands D. Z., Schneider J. D. — J Healthc Manag. — 2010. — № 55. - C. 265-281.

5. Communication in healthcare: a narrative review of the literature and practical recommendations / Vermeir P., Vandijck D., Degroote S. et al. // Int J Clin Pract. 2015. — № 69 (11). — C. 1257-1267.

6. The role of information technology in healthcare communications, efficiency, and patient safety: application and results / Prince S. B., Herrin D. M. // J Nurs Admin. — 2007. — № 37. — C. 184-187.

7. Measuring the effects of health information technology on quality of care: a novel set of proposed metrics for electronic quality reporting / Kern L. M., Dhopeshwarkar R., Barron Y. et al. // Jt Comm J Qual Patient Saf . 2009. — № 35. — C. 359-369.

8. World health report 2010. Health systems financing: the path to universal coverage. - Geneva: World Health Organization; 2010. — Режим доступу: https://www. who.int/whr/2010/en/. конфіденційності та якості даних обстеження та моніторингу стану здоров'я пацієнтів.

3. Забезпечення безперервності надання медичної допомоги, в тому числі, й у дистанційному форматі в рамках комплексної (трансмуральної) моделі організації охорони здоров'я потребує єдиної шкали оцінки надання медичної допомоги.

\section{References.}

1. Kodner, D. L., Spreeuwenberg, C. (2002). Integrated Care: Meaning, Logic, Applications, and Implications A discussion paper. International Journal of Integrated Health Care Archive, 2, 12.

2. Gröne, O., Garcia-Barbero, M. (2001). Trends in Integrated Care - Reflections on Conceptual Issues. World Health Organization, Copenhagen, 10.

3. Cruess, R. L., Cruess, S. R., Steinert, Y. (2018). Medicine as a community of practice: Implications for medical education. Acad Med., 93, 185-91.

4. Agarwal, R., Sands, D. Z., Schneider, J. D. (2010). Quantifying the economic impact of communication inefficiencies in U.S. hospitals. J Healthc Manag., 55, 265-81.

5. Vermeir, P., Vandijck, D., Degroote, S. et al. (2015). Communication in healthcare: a narrative review of the literature and practical recommendations. Int J Clin Pract., 69 (11), 1257-67.

6. Prince, S. B., Herrin, D. M. (2007). The role of information technology in healthcare communications, efficiency, and patient safety: application and results. $J$ Nurs Admin., 37, 184-7.

7. Kern, L. M., Dhopeshwarkar, R., Barron, Y. et al. (2009). Measuring the effects of health information technology on quality of care: a novel set of proposed metrics for electronic quality reporting. Jt Comm J Qual Patient Saf., 35, 359-69.

8. World health report 2010. Health systems financing: the path to universal coverage. World Health Organization. URL: https://www.who.int/whr/2010/en/. 